Cumhuriyet Üniversitesi Fen Fakültesi Fen Bilimleri Dergisi (CFD), Cilt 37, No. 3 (2016) ISSN: $1300-1949$
Cumhuriyet University Faculty of Science Science Journal (CSJ), Vol. 37, No. 3 (2016) ISSN: 1300-1949

http://dx.doi.org/10.17776/csj.42816

\title{
Mantıda Farklı Kurutma Yöntemlerinin Hidroksimetil Furfural (HMF) Oluşumu ve Duyusal Kalite Üzerine Etkileri
}

\author{
Süleyman GÖKMEN ${ }^{1 *}$, Abdulvahit SAYASLAN ${ }^{2}$, Abdullah ÇAĞLAR ${ }^{3}$ \\ *Karamanoğlu Mehmetbey Üniversitesi, Teknik Bilimler Meslek Yüksekokulu, Gıda İsleme Bölümü, Karaman \\ ${ }^{2}$ Karamanoğlu Mehmetbey Üniversitesi, Mühendislik Fakültesi, Gıda Mühendisliği Bölümü, Karaman \\ ${ }^{3}$ Afyon Kocatepe Üniversitesi, Mühendislik Fakültesi, Gıda Mühendisliği Bölümü, Afyon
}

Received: 06.05.2016; Accepted: 18.07.2016

\begin{abstract}
Özet. Ülkemizde mantının kurutulmasında geleneksel sıcak hava yöntemleri kullanılmaktadır. Bu yöntemler üründe kalite kayıplarına neden olmaktadır. Bu nedenle kurutma işlemi için geleneksel tekniklere alternatif yöntemler araştırılmaktadır. $\mathrm{Bu}$ amaçla kullanılabilecek olan bir teknik infrared (IR) kurutma prosesidir. Kurutma proseslerinde en önemli parametreler sıcaklık ve sıcaklığın ürün üzerine etkisidir. Sıcaklığın ürün üzerine olumsuz etkisini gösterebilecek maddelerden biri hidroksimetil furfural (HMF) oluşumudur. HMF enzimatik olmayan esmerleşme reaksiyon ürünlerinden biridir. HMF miktarı arttıkça ürünün besin değerinde düşüşler meydana gelmektedir. Araştırmada, bu olumsuzlukları önlemek amacıyla mantının kurutulmasında geleneksel yönteme alternatif olarak 250 W IR kurutma yöntemi tek başına ve vakum kombinasyonu olarak uygulanmış, oluşan HMF miktarları ve ürün duyusal özellikleri araştırılmıştır. Vakumla kombine edilmiş 250 W IR kullanılarak kurutulan mantıların HMF miktarları geleneksel yönteme göre daha düşük ve duyusal kaliteleri daha yüksek bulunmuştur $(\mathrm{P}<0,01)$. Sonuç olarak, mantının endüstriyel üretiminde IR kurutma ve vakum uygulamasının kombine kullanımı gibi farklı kurutma metotlarının araştırılması gerektiği sonucuna varılmıştır.
\end{abstract}

Anahtar Kelimeler: Mantı, HMF, infrared (IR) kurutma, vakum kurutma, duyusal kalite

\section{Effects of Different Drying Methods of Mantı on Hydroxymethyl Furfural (HMF) Formation and Sensory Quality}

\begin{abstract}
Conventional hot-air drying methods are used in drying of mantı (stuffed pasta) in Turkey. These methods cause quality losses in the product. Therefore search for alternative methods to the conventional drying has been underway. Infrared (IR) drying process is an alternative technique for this purpose. The most important parameters in the drying processes are drying temperature and its effects on the product. Hydroxymethyl furfural (HMF) formation is one of the indicators for illeffects of temperature on the product quality. HMF is one of the nonenzymatic browning reaction products. As the amount of HMF increases, the nutritional quality of the product decreases. In this study, IR drying $(250 \mathrm{~W})$, alone or in combination with vacuum application, was used in drying of mantı as alternative to conventional hot-air drying, and HMF formation and sensory properties of the product were investigated. It was found that the levels of HMF were lower and the sensory qualities were higher in mant1 samples dried by $250 \mathrm{~W}$ IR-vacuum combination than those dried by the conventional method $(\mathrm{P}<0,01)$. It was concluded that different industrial drying methods for mant1, such as IR and vacuum combinations, should be investigated.
\end{abstract}

Keyword: Stuffed pasta (mant1), HMF, infrared (IR) drying, vacuum drying, sensory quality

\section{GíRiş}

Kurutma terim anlamıyla kontrollü şartlar altında 1sı uygulaması sonucu gıdanın bünyesinde bulunan suyun doğrudan ya da dolaylı yolla kütle transferi ile uzaklaştırılması işlemi olarak tanımlanmaktadır [1,2]. Kurutma işlemi yüksek sıcaklıklarda yapıldığından dolayı ürün üzerinde birçok olumsuz etkilere neden olmaktadır. Bunların başlıcaları; ürün kayıpları, renk koyulaşması, tat ve aroma değişimleridir. Bu nedenle farklı kurutma teknikleri günümüzde yaygınlaşmaktadır [3,4]. Bu tekniklerden biri de gıdaların radyasyon ile kurutulmasıdır. Radyasyon tanım itibariyle ışıma meydana getiren unsurlar

\footnotetext{
* Corresponding author. Email address: sugokmen42@hotmail.com
} 


\section{GÖKMEN, SAYASLAN, ÇAĞLAR}

olarak tanımlanmaktadır. Radyasyon iyonize olan ve iyonize olmayan olmak üzere 2 kısım altında incelenmektedir. İyonize olan radyasyonlara gama ve nötron, iyonize olmayan radyasyonlara ise infrared (IR) ve ultraviyole örnek olarak verilebilir. IR radyasyonlar dalga boyuna göre NIR (Yakın IR), FTIR (Uzak IR) ve MDIR (Orta IR) olarak 3 kısımda incelenmektedir. IR radyasyonun dalga boyu azaldıkça, güçleri arttıkça, ürünün kalınlıkları azaldıkça ve gıdaların katıdan sıvıya doğru eğilimleri arttıkça IR' nin etkinliği artmaktadır [5]. IR kurutma, günümüzde hızla yaygınlaşma eğilimi gösteren bir kurutma tekniğidir. Gıda ürünlerinde henüz yaygın uygulamaları görülmemekle birlikte, tahıl, un, et, balık, sebze ve makarna kurutulmasıyla ilgili yapılan deneysel çalışmalarda olumlu sonuçlar alınmıştır [6]. Bununla birlikte IR radyasyonların ürün yüzeyinde ani 1sı artışına neden olması, ürün içerisindeki penetrasyon yeteneklerinin sınırlı olması gibi nedenlerden dolayı farklı metotlarla kombine edilerek kullanılması gerekmektedir. Bu metotlardan birisi de vakum ile kurutmadır. Vakumlu kurutma, 1sıya duyarlı gıdaların kurutulmasında kullanılan bir yöntemdir. Kurutma maliyetlerinin yüksek olması nedeniyle ekonomik açıdan ancak pazar değeri yüksek olan 1sıya duyarlı ürünlerin kurutulması için düşünülebilir. Ayrıca ürün yüzeyinde sert bir kabuk tabakası oluşmayacağı için nem difüzyonu ürün kuruyana kadar engellenmeden devam etmektedir [7]. Vakumla kurutulmuş ürünler, genellikle içi gözenekli ve süngersi (puf) bir yapı kazanır. Bu yapı, kuru ürünün suyu bünyesine geri alması sırasında 1slanma yüzeyini arttırarak önemli bir avantaj sağlar [8]. Vakum kurutma düzeneği tek başına kullanılabileceği gibi başka sistemlerle de kombine edilebilir [9]. Bununla birlikte uygulama sıcaklığ1 ve süresi üründe bazı fiziksel ve kimyasal değişimlere neden olmaktadır. Bu kimyasal değişimlerden biri de enzimatik olmayan esmerleşme reaksiyon ürünlerinden olan Hidroksi Metil Furfural (HMF)'dir. Bu bileşen Maillard reaksiyonu esnasında enzimatik olmayan esmerleşme reaksiyon ürünlerinden biri olarak bilinmektedir [11]. Maillard reaksiyonunda oluşan ürünler tepkime giren bileşenlerin çeşidine ve miktarı ile ortamın sıcaklık, $\mathrm{a}_{\mathrm{w}}$ ve pH'sına bağlı olarak değişiklik göstermektedir. Maillard ürünlerinin başlıcaları; HMF, furfural, melanoidler ve akrilamidlerdir [12]. Bu bileşiklerin gıdalarda kalite ve besin kayıplarına da yol açtı̆̆ farklı literatürlerce belirtilmiştir. Bununla birlikte HMF heksozların asidik ortamda doğrudan 1sitılmasıyla da oluşabilmektedir [13].

Kurutma işlemi çoğu gıdalarda raf ömrünü arttırmak, kaliteyi korumak gibi birçok amaçla kullanılmaktadır. Kurutma işlemi uygulanan gıdalardan biri de mantıdır. Mantı ülkemizde sevilerek tüketilen ve besleyici değeri yüksek geleneksel ürünlerimizden biridir. Mantı, çeşitli baharatlarla çeşnilendirilen kıymanın, küçük hamur parçalarının içine konulması ve bu hamur parçalarının suda haşlanması ile yapılan bir etli hamur yemeğidir. Üretilen mantılar taze olarak tüketime sunulabileceği gibi, firınlandıktan veya dondurulduktan sonra da tüketilebilmektedir [10]. Mantının kurutulmasıyla uygulanan sıcaklık ve süreye bağlı olarak kalite kriterlerinde bazı olumsuzluklar meydana gelmektedir. $\mathrm{Bu}$ olumsuzlukları önlemek amacıyla araştırmada mantının kurutulmasında geleneksel yönteme alternatif olarak 250 W IR tek başına ve vakum kombinasyonu uygulanarak HMF miktarlarının mantının bazı kalite kriterleri üzerine etkisi araştırılmıştır. 


\section{MATERYAL ve METOT}

\section{Materyal}

Karaman koşullarında piyasaya sürülen 4 farklı markada bohça tipi, ortalama her biri $1 \mathrm{~g}$ ağırlığında olan 100 g yaş mantılar 3'er tekerrürlü olarak kurutulmuştur. Mantı Resim 1' de verilmiştir.
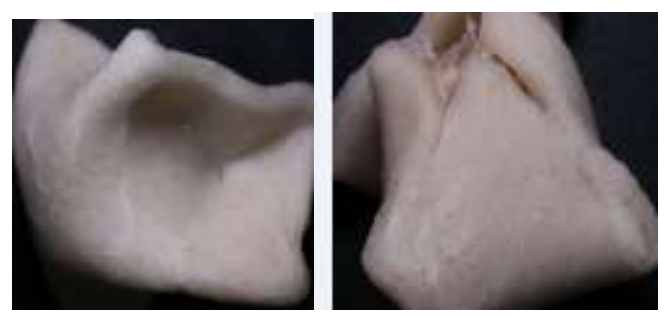

Resim 1. Mant1 Örnekleri.

\section{Metot}

Yaş mantı örnekleri vakumlu etüvün (Nüve 3600) içerisine konulmuş 250 W IR kurutma ve geleneksel yöntem olan $250{ }^{\circ} \mathrm{C}$ 'deki kuru sıcak hava ile kurutulmuştur. Kurutma işlemi mantı örneklerinin başlangıç nemi olan \%36 nemden \%12 neme düşünceye kadar ve her beş dakikada bir ağırlık kayıpları analitik bir terazi ile ölçülerek işleme devam edilmiştir. IR işlemde uygulanan kurutma parametreleri ve kurutma ortamının özellikleri aşağıda verilmiştir.

\section{Kurutma parametreleri}

1. Lamba ile ürün arasındaki uzaklık $25 \mathrm{~cm}$ olarak belirlenmiştir.

2. Kurutma süresi $250 \mathrm{~W}$ IR ile 70 dakika ve $250 \mathrm{~W}$ IR ile 0,4 vakumda ise 64 dakika olarak belirlenmiştir.

\section{Kurutma ortamının özellikleri}

1. Gıda 1sıtmada kullanılan boyu 173 mm, duyu E 27, Voltaj1 $230 \mathrm{~V}$, ömrü 5000 saat olan IR kurutma kullanılmıştır.

2. Emiş gücü 15 lt/dk olan yağsız olarak çalışabilme özelliğine sahip vakum pompa kullanılmıştır.

3. Hacmi 15 1t, iç ebatları 300x250x200 mm, dış ebatları 517x445x530 mm olan 70-200 ${ }^{\circ} \mathrm{C}$ sıcaklık aralığında çalışan vakum etüv kullanılmıştır.

\section{Duyusal Analizler}

Kaynamakta olan $400 \mathrm{ml}$ suya 100 gram mantı ve karışım ağırlığının %1'i kadar tuz konularak 12-15 dakika haşlanır. Mantıların yüzeyde toplanması piştiğinin gösteresi olduğu kabul edilmiştir. Haşlanmış ve yüzeyde toplanmış olan mantılara $75 \mathrm{ml}$ soğuk su ilave edilmiştir [14]. Sitti ve ark. [10] tarafindan hazırladıkları ve mantının duyusal kaliteyi tespit etmek amacıyla belirttikleri parametreler dikkate alınarak aşağıdaki duyusal analiz formu kullanılmıştır ( Tablo1 ve Tablo 2). 
GÖKMEN, SAYASLAN, ÇAĞLAR

Tablo 1. Mantının duyusal özellikleri ile ilgili kriterler.

\begin{tabular}{|l|l|}
\hline Özellikler & Kriterler \\
\hline Tat ve koku & $\begin{array}{l}\text { Pişirilmeden önce kendine özgü kokuda ve pişirildikten sonra kendine özgü tat ve kokuda olmalı, } \\
\text { ekşime, küflenme, kokuşma ve bozulma, yabancı tat ve/veya koku olmamalıdır. }\end{array}$ \\
\hline $\begin{array}{l}\text { Renk ve } \\
\text { görünüş }\end{array}$ & $\begin{array}{l}\text { İç malzeme olarak kullanılan malzemeler pişmeden önce ve sonra kendine özgü renk ve görünüşte } \\
\text { olmalıdır. }\end{array}$ \\
\hline Yap1 & $\begin{array}{l}\text { Mantılarda pişmeden önce çözünme, parçalanma, birbirine yapışma, iç malzemede dişarıya çıkma } \\
\text { olmamalıdır. Kaynar suya atıldığında en çok 20 dakikada pişmelidir. Piştikten sonra kaygan, parlak } \\
\text { olmalı ve dağılmış olmamalıdır. }\end{array}$ \\
\hline $\begin{array}{l}\text { Yabanc1 } \\
\text { madde }\end{array}$ & \begin{tabular}{l} 
Bulunmamalıdır. \\
\hline
\end{tabular}
\end{tabular}

Mantılarının duyusal analiz puanlanması Tablo 2' ye göre yapılmıştır. Tablo 2 aşağıda verilmiştir.

Tablo 2. Duyusal Analiz Formu.

\begin{tabular}{|c|c|c|c|c|}
\hline \multirow[t]{5}{*}{ Panelist No } & Tat & Koku & Ağız Hissi & Görünüş ve Genel Beğeni \\
\hline & $\begin{array}{l}\text { 1-3: Farkl1 Tat } \\
\text { Belirgin }\end{array}$ & 1-2: Belirgin Koku & 1: Çok Yumuşak & 1: Kötü \\
\hline & $\begin{array}{l}\text { 4-7:Orta Dereceli } \\
\text { Mantı Tadı }\end{array}$ & $\begin{array}{l}\text { 3-4: Mantiya Has Koku } \\
\text { Biraz Var }\end{array}$ & $\begin{array}{l}\text { 2: Yumuşak } \\
\text { 3-4: Orta Derece } \\
\text { Yumuşak }\end{array}$ & $\begin{array}{l}\text { 2: Çok } \\
\text { 3: Orta Derece }\end{array}$ \\
\hline & \multirow[t]{2}{*}{$\begin{array}{l}\text { 8-10: Tamamen } \\
\text { Mantı Tadı }\end{array}$} & $\begin{array}{l}\text { 5-7: Mantiya Has Koku } \\
\text { Daha Fazla }\end{array}$ & 5-6: S1k1 & $\begin{array}{l}\text { 5-6: Az } \\
\text { 7-8: Çok Az }\end{array}$ \\
\hline & & $\begin{array}{l}\text { 8-10: Tamamen Mantiya } \\
\text { Has Koku }\end{array}$ & $\begin{array}{l}\text { 7-8: Biraz Sert } \\
\text { 9-10: Çok Sert }\end{array}$ & 8-10: Çok İyi \\
\hline
\end{tabular}

\section{HMF tayini}

Örneklerin HMF miktarını tespit etmek için spektrofotometrik olarak HMF analizi yapılmıştır [15]. Bu amaçla UV- spektrofotometre (Agilent 8453 E UV-Visible Spectroscopy System, U.S.A) kullanılmıştır.

Metot aşağıdaki aşamaları içermektedir.

1. Örneklerin homojenize edilmesini,

2. Asit hidrolizini, 


\section{Mantıda Farklı Kurutma Yöntemlerinin Hidroksimetil Furfural}

3. Proteinlerinin çöktürülmesini,

4. Çökeltinin ayrılmasını,

5. Berrak fazın türevlendirilmesi, hidrolizi, inkübasyonu ve soğutulmasını,

6. Elde edilen fazın filtre edilmesi ile elde edilen filtratın $443 \mathrm{~nm}$ de absorbasının ölçülmesini,

7. Bulunan değerin aşağıdaki formülde yerine konularak örnekteki HMF miktarının hesaplanmasını kapsamaktadır.

100 g örnekteki HMF miktarı $(\mu \mathrm{M})=(\mathrm{A} 443-0,055) \times 87,5$

A443: Ölçülen Absorbans değeri

$\mu \mathrm{M}$ : Mikrometre

Elde edilen sonuçlar örneklerdeki HMF’nin p-toluidin ve barbütirik asit ile oluşturduğu kırmızı rengin absorbansının spektrofotometrede (550 nm dalga boyunda) ölçülmesiyle doğrulanmıştır [16].

\section{pH tayini}

$10 \mathrm{~g}$ örnek $90 \mathrm{~mL}$ distile su ile homojenize edilmiştir. Kalibre edilmiş olan pH metre (Inolab-pH 7110, Germany) kullanılarak örneklerin pH değerleri belirlenmiştir [17].

\section{İstatistiksel Analizler}

Kurutma metotları ile örneklerin HMF miktarları ve duyusal analiz parametreleri arasındaki farklılıkların belirlenmesi için çoklu varyans analizi yapılmıştır. Jump programı kullanılarak Anova çoklu karşılaştırma testi uygulanmış ve sonuçlar \%90'lık güven aralığında istatiksel olarak değerlendirilmiştir.

\section{SONUÇLAR VE TARTIŞMA}

\section{HMF değerleri}

HMF değerleri istatistiksel açıdan önemli bulunmuştur $(\mathrm{P}<0,01)$. Geleneksel yöntemlerle üretilen mantıların HMF değeri en yüksek seviyede vakum ve IR lambanın birlikte uygulandığı örneklerin HMF değerleri en düşük seviyede bulunmuştur (Şekil 1). 


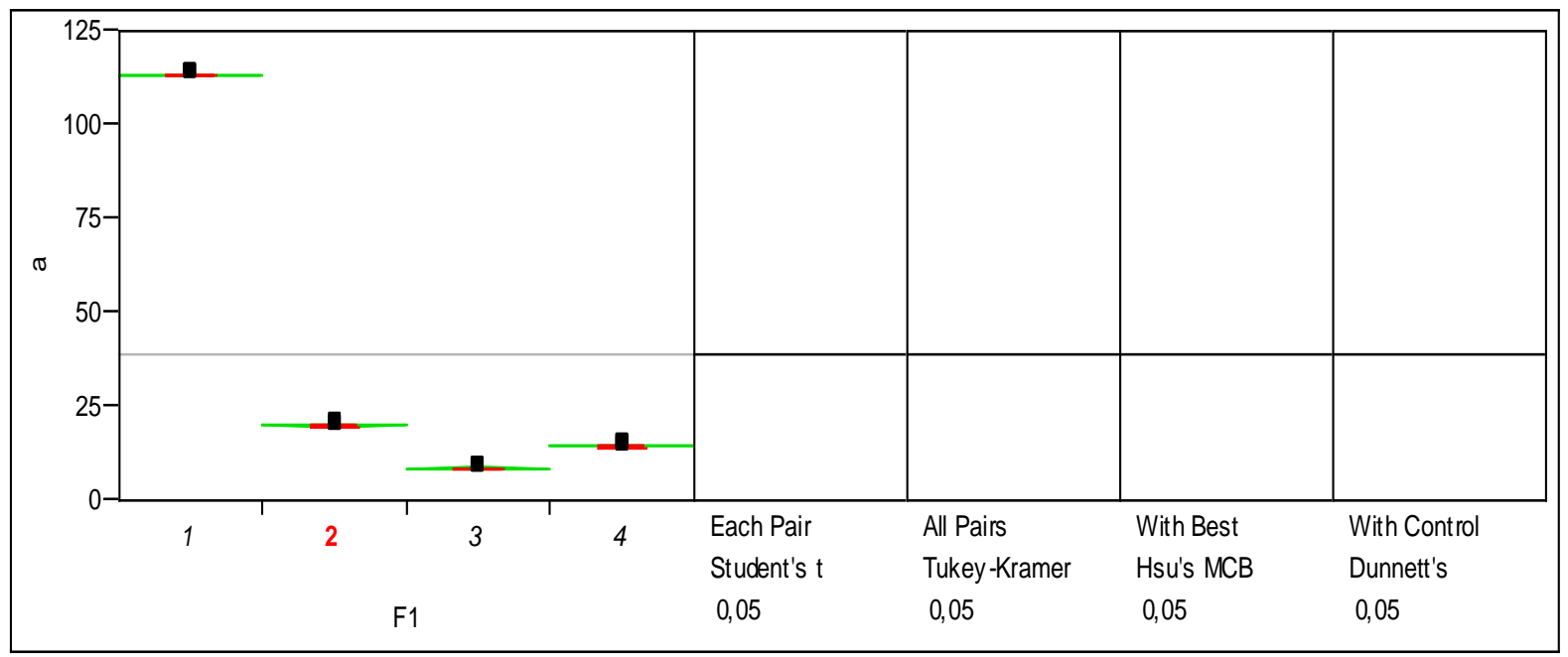

1. Geleneksel yöntem, 2. Kontrol, 3. 250 IR+Vakum, 4. 250 W IR ile kurutulmuş mantılar Şekil 1. Örneklerin HMF (a) miktarları $(\mu \mathrm{M})$.

\section{pH değerleri}

Mantı örneklerinin pH değerleri 6.1-6.2 arasında olduğu tespit edilmiştir. Örnekler arasında pH değerleri açısından önemli bir farklılık bulunmamıştır ( $p>0.01)$.

\section{Duyusal Analiz Sonuçları}

Duyusal analizlerden genel görünüş ve genel beğeni değerleri açısından örneklerde istatistiki açıdan önemli bir fark bulunmamıştır $(\mathrm{p}>0.01)$. Duyusal analizlerden koku/aroma değerleri açısından örneklerde istatistiki açıdan önemli bir fark (Şekil 2) bulunmuştur $(\mathrm{p}<0,01)$. Geleneksel yöntemlerle üretilen mantılar koku/aroma değerleri açısından en düşük değeri alırken (Şekil 2) IR ve IR+vakum ile üretilen mantılar en yüksek değerleri almıştır (Şekil 2). Duyusal analizlerden tekstür/doku değerleri açısından örneklerde istatistikî açıdan önemli (Şekil 2) bir fark bulunmuştur ( $p<0,01$ ). Geleneksel yöntemlerle üretilen mantılar tekstür/doku parametresi açısından en düşük değeri alırken IR ve IR+vakum ile üretilen mantılar en yüksek değerleri almıştır (Şekil 2). 


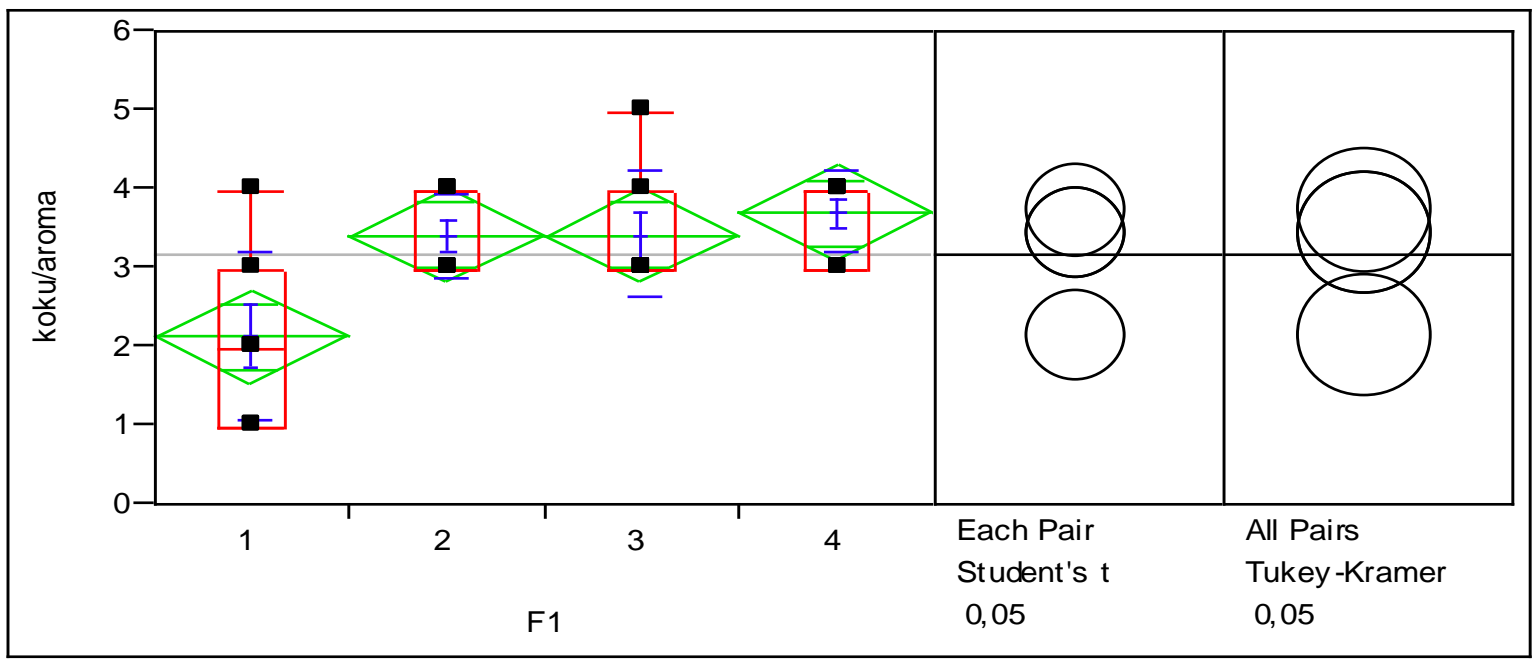

1. Geleneksel yöntem, 2. Kontrol, 3. 250 IR+Vakum, 4. 250 W IR ile kurutulmuş mantılar

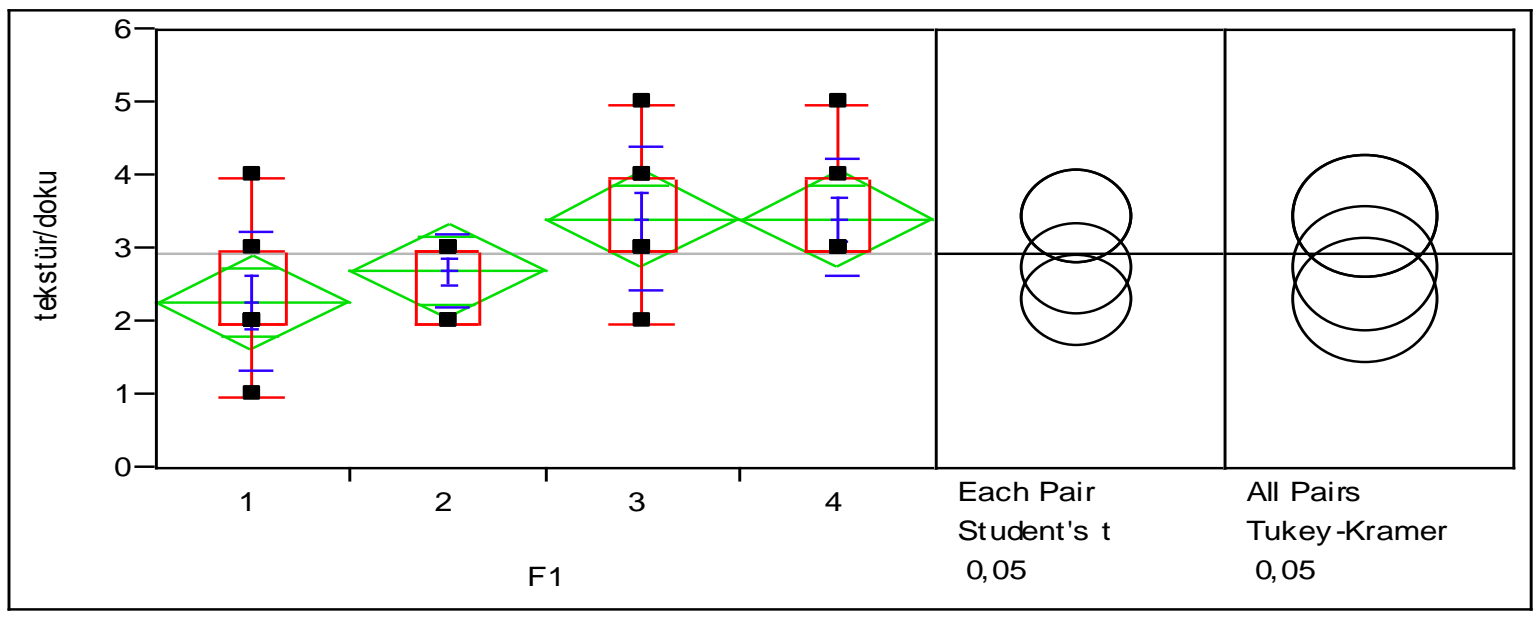

1. Geleneksel yöntem, 2. Kontrol, 3. 250 IR+Vakum, 4. 250 W IR ile kurutulmuş mantılar 


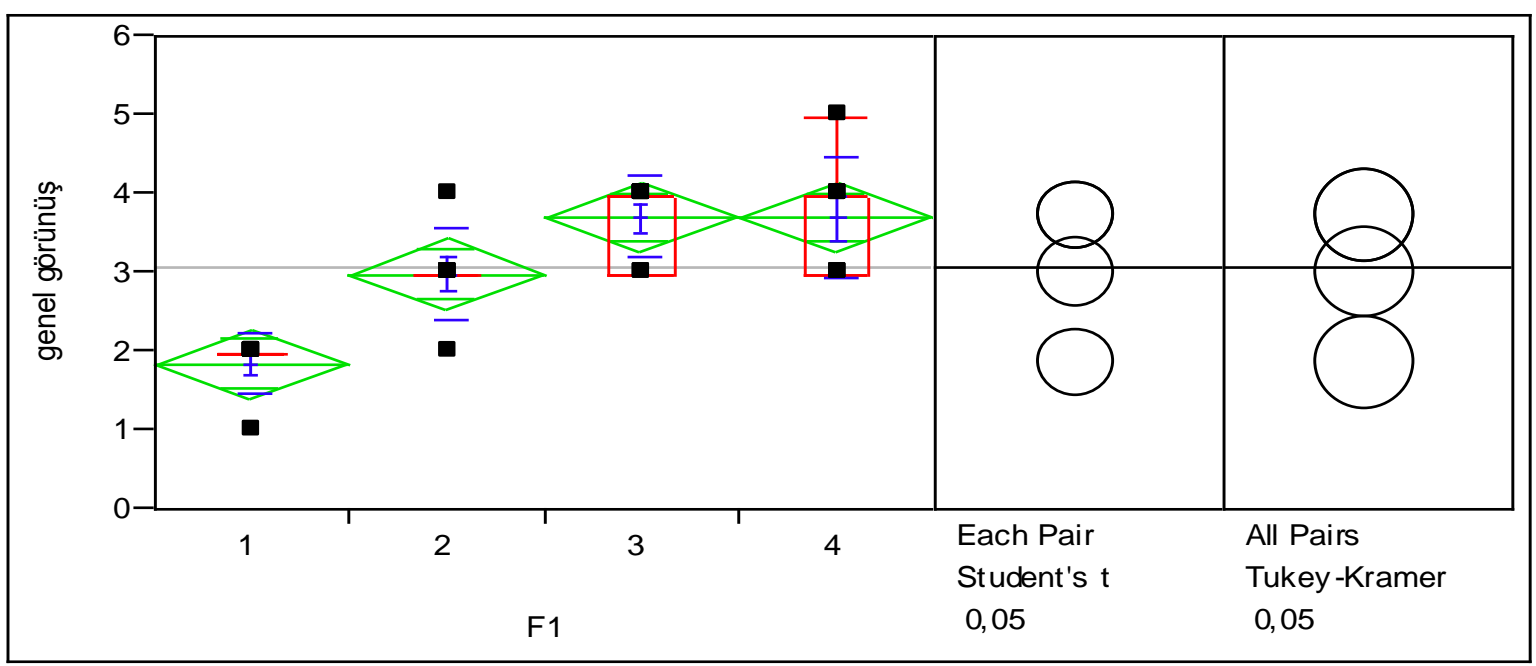

1. Geleneksel yöntem, 2. Kontrol, 3. 250 IR+Vakum, 4. 250 W IR ile kurutulmuş mantılar

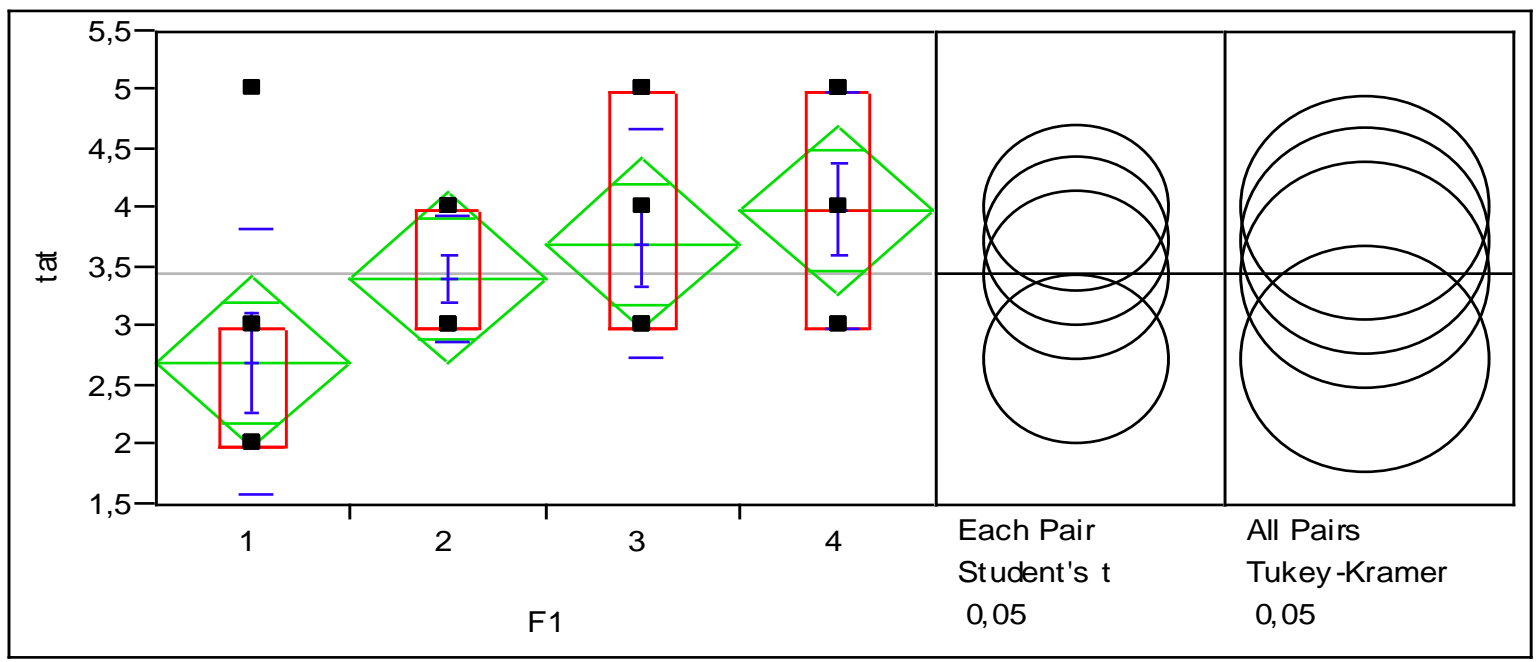

1. Geleneksel yöntem, 2. Kontrol, 3. 250 IR+Vakum, 4. 250 W IR ile kurutulmuş mantılar 


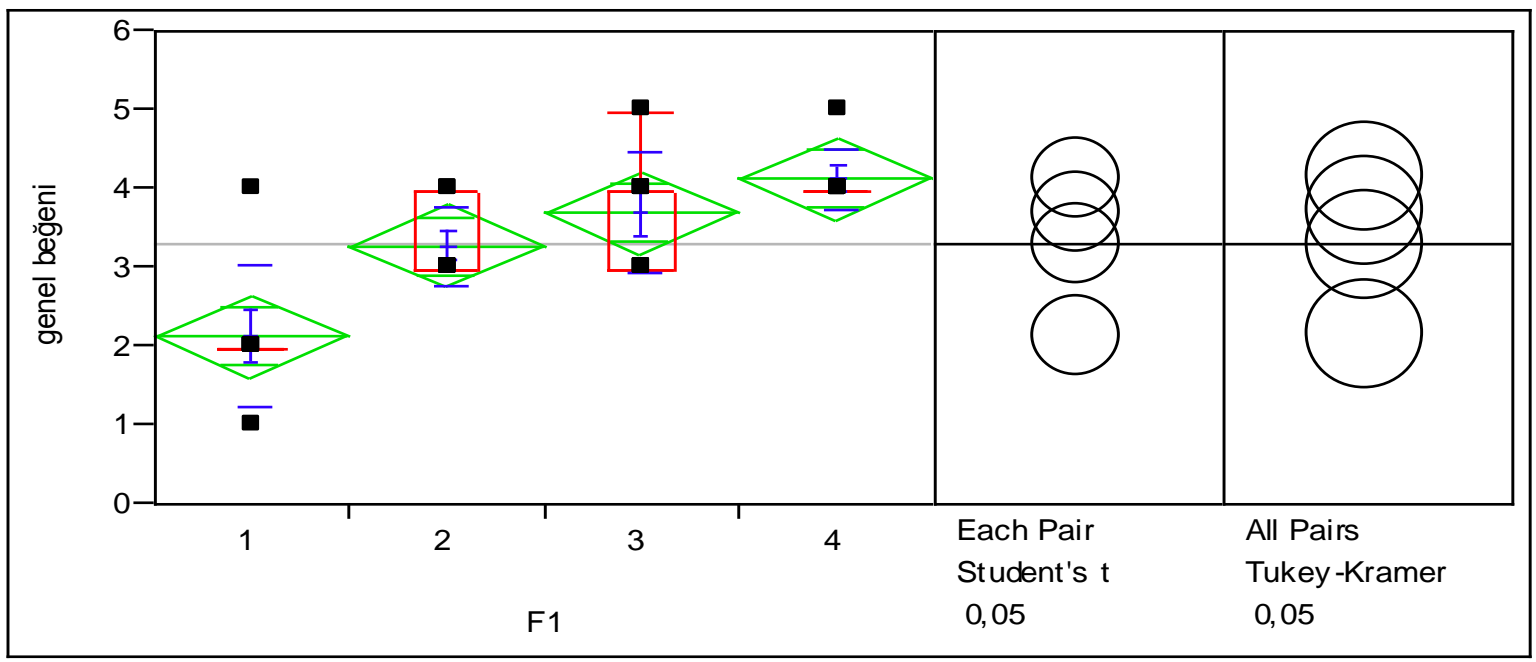

1. Geleneksel yöntem, 2. Kontrol, 3. 250 IR+Vakum, 4. 250 W IR ile kurutulmuş mantılar

Şekil 2. Örneklerin Duyusal Analiz Sonuçları (Görünüş-koku-aroma-tekstür-doku-tat ve genel beğeni).

Mantı örneklerinin kurutma süreleri 250 W IR 70 dakika, 250 W IR + vakum 64 dakika, geleneksel yöntem de ise 35 dakika olarak bulunmuştur. Kurutma ortamının sıcaklık dereceleri ise 250 W IR 105 ${ }^{\circ} \mathrm{C}$ ve $250 \mathrm{~W}$ IR + vakumda $98^{\circ} \mathrm{C}$ olarak ölçülmüştür. Unlu mamuller dışında IR kurutma uygulamaları meyvelerde, sebzelerde, baharatlarda, kırmızı ette, köftelerde ve unlu mamullerde geleneksel yöntemlere göre kurutma sürelerini kısaltmıştır [17-19]. Ancak IR uygulamalarının kurutma süresini kısaltması kullanılan lambaların güçlerine, IR' nin dalga boyuna, lamba sayısına, başka bir kurutma yöntemiyle kombine edilip edilmemesine ve gıdanın yapısal özelliklerine bağlı olarak değişiklik göstermektedir [4]. Çalışmamızda düşük güçte IR kullanılması mantının kurutma süresini uzatmıştır. Bunun yanı sıra IR' nin vakum ile kombine edilmesi kurutma süresini kısaltmıştır.

Araştırma sonuçlarında HMF miktarları geleneksel yöntemle üretilen mantılarda IR ile ve IR + vakum kombinasyonu ile kurutulan mantılara kıyasla oldukça yüksek çıkmıştır. HMF enzimatik olmayan esmerleşme reaksiyonlarından biridir. HMF genellikle şeker bazlı ürünlerde fazla görülürken, süt ve tahıl ürünlerinde de sıklıkla rastlanmaktadır. Unlu mamullerde yapılan çalışmalarda; ortam sıcaklığının artması (HMF oluşumu 50 C' nin üzerinde başlamakta), pH'nın 4-7 arasında olması, nem düzeyinin normal seviyelerde olması, ürün ağırlıklarının yüksek, üründe kabuk kitlesinin kalın ve işlem süresinin uzun olması ürünlerde HMF miktarını arttırdığı bildirilmiştir [20]. Çalışmamızda ise ortam sıcaklığının geleneksel yöntemde yüksek olması $\left(250^{\circ} \mathrm{C}\right)$, geleneksel yöntemde kulanılan kuru sıcak havanın penetrasyonunun düşük olmasından dolayı örneklerin yüksek sıcaklığı maruz kalma süresini uzatmış ve netice olarak yöntem örneklerin HMF miktarını arttırmıştır. Bunun yanı sıra mantı örneklerinin ağılık, hamur kalınlığı ve asitlik derecelerinin birbirlerine yakın olmasından dolayı bu özelliklerin örneklerin HMF miktarlarına önemli bir düzeyde etki etmediğinin sonucuna varılmıştır. IR radyasyonun düşük 


\section{GÖKMEN, SAYASLAN, ÇAĞLAR}

güçlerde ve vakum ortamda kullanılması, mantı örneklerinin HMF miktarlarını düşürdügü tespit edilmiştir. Ayrıca geleneksel yöntemin kurutma süresinin kısa olması (35 dakika) HMF miktarının IR' ye göre çok yüksek olmasını engelleyememiştir. Bunun en büyük nedeni sıcaklığın geleneksel yöntemde yaklaşık 2.5 kat fazla olmasından kaynaklandığı düşünülmektedir. Yapılan bir çalışmada HMF miktarı ekmekte renk, tat ve aroma oluşumuna etki ettiği rapor edilmiştir. Bu nedenle HMF'nin artması mantılarda duyusal kaliteyi düşürdüğü belirlenmiştir. Diğer bir çalışmada ise eriştelerde geleneksel yöntemlere göre IR'nin uygulanması ürünün kurutma süresini kısaltıp, pişirme kaybını azaltmıştır [2122]. Ayrıca unlu mamullerin pişirilmesinde IR kurutmanın kullanımı geleneksel yöntemlere göre ilk yatırım maliyetini ve enerji sarfiyatını azaltmış olduğu bildirilmiştir [22-26]. Ayrıca geleneksel yönteme göre IR uygulaması, çoğu gıdaların (erişte, ekmek, galeta üretiminde) duyusal kalitesini arttırmış olduğu rapor edilmiştir [17-19, 22-25]. Çalışmamızda da IR ile kurutulan mantı örneklerinin duyusal kalitesinin yüksek olduğu tespit edilmiştir.

Çalışmamızda mantılar IR ile IR+vakum ve geleneksel yöntemlerle kurutulmuştur. IR+ vakum tek başına kullanılan IR' lere göre hem kurutma süresini kısalttı̆̆ından hem de üründe HMF düzeylerini azalttığından dolayı mantıların duyusal kalitesine olumlu yönde etkilemiştir. Bu bilgiler ışığında; mantıların kurutulmasında IR radyasyonun ve vakum kombinasyonunun kullanılabileceğinin sonucuna varılmıştır.

\section{KAYNAKLAR}

1. Yildı, O., Ertekin, C., Thin Layer Solar Drying of Some Vegetables, Dryıng Technology, (2001), $19: 583-597$.

2. Ratti, C., Hot-air and Frezee-drying of High Value Foods: A Review.Journal of Food Engineering, (2001), 49:311-319.

3. Anonim,PACStaff."Near, Mid and Far-IR".NASA

IPAC,USA,http://www.ipac.caltech.edu/outreach/Edu/Regions/irregions.html, Jun 2013.

4. Erdoğdu, B., Kısa Dalga Ultraviole (UVC) Işınların Gıdalarda Yüzey Pastörizasyonu İle Kısa Dalga Ultraviole ve Uzak IR (FIR) Işınların Tane Karabiber ve Kimyon Pastörizasyonunda Kullanımının Araştırılması, Doktora Tezi, Mersin Üniversitesi, Fen Bilimleri Enstitüsü, Gıda Mühendisliği Anabilim Dalı, Mersin 2011.

5. İçier, F., Yıldız, H., Elektriksel Yöntemlerin Gıdaların Kalite Özellikleri Üzerine Etkileri, Gıda, (2003), 30-4:255-260.

6. Nasıroglu, Ş., Kocabıyık,H., Thın-Layer IR Radıatıon Dryıng Of Red Pepper Slıces, Journal of Food Process Engineering, (2009), 32,1-16.

7. Ayhan,A., Çeşitli Tarımsal Ürünlerin Vakumla Kurutulmasında Kurutma Parametrelerinin Belirlenmesi, Yüksek Lisans Tezi, Uludağ Üniversitesi, Fen Bilimleri Enstitüsü, Tarım Makineleri Anabilim Dal1, Bursa, 2005.

8. Yağcıŏlu, A., Tarım Ürünleri Kurutma Tekniği, Ege Üniversitesi, Ziraat Fakültesi Yayınları No: 536, İzmir,1999.

9. Yongsawatdigul, J., Microwave-Vacuum Drying of Cranberries,Part II. Quality Evaluation,1995.

10. Sitti, S., Kayseri Mantısı: Hazırlanışı ve Kalite Nitelikleri, II. Geleneksel Gıdalar Sempozyumu, (27-29 Mayıs 2009), Yüzüncü Y1l Üniversitesi, Van.

11. Oral, R.A., Doğan, M., Sarığlu, K., Organik Asit-fruktoz Model Sisteminde Bazı Fenolik Bileşiklerin HMF Oluşumu Üzerine Etkileri, Gıda Teknolojileri Elektronik Dergisi, (2013), 8-2, 12-17. 
12. Block, J.D., Merchiers, M., Mortier, L., Braekman, A., Ooghe, W., Renterghem, R.V., Monitoring nutritional quality of milk powders: capillary electrophoresis of the whey protein fraction compared with other methods. International Dairy Journal, (2003),13, 87-94,.

13. Janzowski, C., Glaab, V., Samimi, E., Schlatter, J., Eisenbrand, G., 5-Hydroxymethylfurfural: assessment of mutagenicity, DNA- damaging potential and reactivity towards cellular glutathione. Food and Chemical Toxicology, (2000), 38, 801-809.

14. Baysal, A., Türk Yemek Kültüründe Değişmeler, Beslenme ve Sağlık Yönünden Değişmeler. Türk Mutfak Kültürü Üzerine Araştırmalar, Türk Halk Kültürünü Araştırma ve Tanıtma Vakfı Yayınları, Ankara. Yayın No: 3, 1993, s.12-21.

15. Dokuzlu, C., Gıda Analizleri, Marmara Kitabevi Yayınları, Bursa, Eylül 2004.

16. Anonymous, Determination of HMF. IFFJP Analyses No:12, P 4,1972.

17. Arslan, N., IR Kurutma Yönteminin Kurutulmuş Mantı Kalitesi Üzerine Etkisi, Yüksek Lisans Tezi, Çanakkale 2012.

18. Nasıroglu, Ş., Kocabıyık,H., Thın-Layer IR Radıatıon Dryıng Of Red Pepper Slıces, Journal of Food Process Engineering, (2009), 32,1-16,

19. Riadh, M.H., Siti, A. B. A., Marhaban, M.H., Azura, C. S., Infrared Heating in Food Drying: An Overview, Drying Technology, 33 (2015), 322-335.

20. Batu, A., Aydoymuş, R.E., Batu, H.S., Gıdalarda Hidroksimetilfurfural (HMF) Oluşumu ve İnsan Sağlığ1 Üzerine Etkisi, Electronic Journal of Food Technologies, 9.1 (2014): 40-55.

21. Basman,A., Yalçın,S., 2011. Quick-Boiling Noodle Production By Using IR Drying. Journal of Food Engineering,(106): 245-252.

22. Tireki, S., Sumnu, G., Esin, A., 2006. Production of Bread Crumbs By IR-Assisted MicrowaveDrying. European Food Research and Technology, 2(1-2) : 8-14.

23. Hamanaka, D.,Uchino,T.,Inoue,A.,Kawasaki,K.,Hori,Y., 2006. Develeopment of The Rotating Type Grain Sterilizer Using IR Radiation Heating, In Proceedings of the 13th World Congress of Food Science Tecnology, 2006, France, p. 361.

24. Skjoeldebrand, C. Andersson, C., 1989. A Comparison of Infrared Bread Baking and Conventional Baking. Journal of Microwave Power Electromagetic Energy, (24) : 91-101.

25. Keskin, S.O., Sumnu, G., Sahin, S., 2007. A Study on The Effects of Different Gums on Dielectric Properties and Quality of Breads Baked in Infrared Microwave Combination Oven. Europen Food Research Technology,(224) : 329-334.

26. Sheridan, P.S., Shilton, N.C., 2002. Analysis of Yield While Cooking Beefburger Patties Using Far Infrared Radiation. Journal Food Engineering, (51) : 3-11. 